Inajá Tavares ${ }^{1}$ Maria Adélia Minghelli Pieta ${ }^{2}$ Maria Eduarda Pedroso ${ }^{3}$ Ana Cristina Garcia Dias ${ }^{2}$
SELF-GUIDED INTERNET-BASED COGNITIVE-BEHAVIORAL INTERVENTIONS FOR ADOLESCENTS: A REVIEW

\section{INTERVENÇÕES COGNITIVO-COMPORTAMENTAIS BASEADAS NA INTERNET AUTOGUIADAS PARA ADOLESCENTES: UMA REVISÃO}

\section{ABSTRACT}

The management of psychological disorders has been the focus of different self-guided cognitive-behavioral interventions mediated by technologies through computer and smartphone applications. The aim of this study was to identify and describe interventions such as those aimed at adolescents. For this, an integrative literature review was conducted in PsycINFO, Scopus, and Web of Science databases, using four blocks with descriptors that represented: self-guided applications, types of interventions, cognitivebehavioral therapy and adolescents. After the process of analyzing and selecting the 93 results found, the final sample consisted of 19 articles referring to 13 interventions. These have been described in efficacy studies with more than one group, protocols to assess efficacy, pilot investigations, complementary aspects studies, and case studies. Anxiety and depression were the main therapeutic targets and 9 articles showed favorable results for the interventions use. Despite considering the potential to effectively optimize and streamline mental health care, it is clear how incipient are investigations based on cognitive-behavioral therapy in mobile health with adolescents.

Keywords: :Cognitive Behavioral Therapy; Adolescent; Mobile Applications.

\section{RESUMO}

O manejo de transtornos psicológicos tem sido foco de diferentes intervenções cognitivocomportamentais autoguiadas mediadas por tecnologias por meio de aplicativos para computadores e smartphones. O objetivo deste estudo foi identificar e descrever intervenções do tipo voltadas para adolescentes. Para isso, realizou-se uma revisão integrativa de literatura nas bases PsycINFO, Scopus e Web of Science, utilizando quatro blocos com descritores que representavam: aplicações autoguiadas, tipos de intervenções, terapia cognitivocomportamental e adolescentes. Após o processo de análise e seleção dos 93 resultados encontrados, compuseram a amostra final 19 artigos referentes a 13 intervenções. Estas foram descritas em estudos de eficácia com mais de um grupo, protocolos para avaliar eficácia, investigações-piloto, estudos de aspectos complementares e estudos de caso. Ansiedade e depressão foram os principais alvos terapêuticos, e 9 artigos apontaram resultados favoráveis ao uso das intervenções. A maior parte das intervenções foi inteiramente autoguiada e ofertada exclusivamente via website, por vezes incluindo algum nível de participação dos cuidadores. Apesar de considerar-se o potencial de otimizar e agilizar o atendimento à saúde mental de forma efetiva, constata-se o quão incipientes são as investigações baseadas em terapia cognitivo-comportamental em saúde móvel com adolescentes.

DESCRITORES: Terapia Cognitivo-comportamental; Adolescente; Aplicativos móveis. 


\section{INTRODUCTION}

Adolescence is the developmental period that marks the transition from childhood to adulthood. Different criteria can be used to delimitate this stage of human development, with many studies using the chronological criterion that covers the period from 10 to 20 years of age (Steinberg, 2016). This lifecycle stage involves specific developmental tasks and changes in social roles, in addition to biological, cognitive, and emotional transformations (Steinberg, 2016).

Hormonal changes during puberty imply transformations that lead to changes in emotional and behavioral reactions (Silva et al., 2017). In turn, cognitive processes become more efficient halfway through this developmental stage. At such phase, thought stimulation can produce a critical difference since activities and experiences of this period determine which neural connections will be maintained and strengthened (Kuhn, 2006). Concerning developmental tasks, there is a search, by young people, for developing their autonomy - considering the challenge of establishing themselves as independent, both emotionally and functionally (Steinberg, 2016).

During adolescence, symptoms of anxiety and/or depression are some of the main causes of psychopathologies' presence and/or functional disability. Deaths by suicide are the third leading cause of death in the 15-19 age group (Pan American Health Organization [PAHO], 2018). In Brazil, a physical and mental health assessment of 74,589 school adolescents revealed a $30 \%$ prevalence of common mental disorders - characterized by presence of symptoms of depression and anxiety, in addition to somatic complaints (Lopes et al., 2016). In the United Kingdom, the incidence of anxiety disorders increased between 2003 and 2018, mainly in the 17 to 19 age group (with a higher incidence range for males - 316 per 10,000 people) (Cybulski et al., 2021). In the United States, an estimated $14.4 \%$ of youth ages 12-17 experienced at least one episode of Major Depressive Disorder (MDD) in 2018 (SAHMA, 2019).

In general, emotional disorders can become profoundly disabling, affecting young people's learning, social adjustment, interpersonal relationships, emotional and intellectual development (Pupo-González et al., 2018). Although half of all mental health conditions begin by age 14 and an estimated $10 \%$ to $20 \%$ of adolescents experience psychopathology, many remain inadequately diagnosed and treated (PAHO, 2018). Psychopathologies are not rare among young people and their consequences call attention to the need to think about interventions for this public.

Since adolescents are familiar with and interested in technologies, it is estimated that structured psychological interventions offered through the internet, using applications, can benefit this group. It is also assumed that such interventions can increase their access to psychological treatments, as many of these individuals do not receive psychotherapeutic care due to limited resources and individual barriers (Topooco et al., 2018).

This understanding aligns with the encouragement and growth of interventions using digital technologies in prevention and health promotion (e-Health), accessible via mobile devices (WHO, 2019). To this end, applications (apps) are developed, consisting of computer programs designed for a specific purpose that can be downloaded to cell phones or other mobile devices (Cambridge Dictionay, 2021). Specifically, in mental health area, internet-based interventions stand out. These are self-help programs offered through mobile devices or the web, entirely self-guided or supported by a therapist (Borgueta et al., 2018).

This professional support can be synchronous (with simultaneous interaction) or asynchronous (with non-simultaneous interaction). Interventions are generally short-term, usually 5-10 modules per week. For example, a program that includes informational text and graphics, audio instructions for relaxation, illustrative video of cases, therapist support via email, and automatic email and/or SMS reminders (Proudfoot et al., 2011).

When based on cognitive-behavioral therapy (CBT) techniques, these interventions are called internet-based Cognitive Behavior Therapy (iCBT). In iCBT, patients have access to online materials that seek to provide the same tools presented in face-to-face CBT (Mehta et al., 2018). iCBT has demonstrated efficacy in treating anxiety symptoms in adults (Stefanopoulou et al., 2018), and immediate and sustained reduction of depressive symptoms (Sztein et al., 2017). Internet-based interventions, offered as an adjunct to traditional psychotherapy or as self-guided psychological treatments, have numerous advantages including the fact that treatment is available at any time and place and patients can work at their own pace and review material as often as they wish (Spek et al., 2006).

With Covid-19 pandemic, there was a deterioration in people's mental health and well-being indices (Brooks et al., 2020; Ravens-Sieberer et al., 2020). Regarding young people, studies show worsening of conditions associated with adolescent mental health during coronavirus crisis (Ravens-Sieberer et al., 2020; Xie et al., 2020), with $48.2 \%$ and $36.7 \%$ prevalence of depressive and anxiety symptoms respectively (Liang et al., 2020). Furthermore, the pandemic disproportionately affects children and adolescents who are socially disadvantaged (Fegert et al., 2020; Ravens-Sieberer et al., 2020). Due to social distancing rules, remote interventions emerge as viable alternatives to help reduce these impacts, as they allow interventions to be delivered without having to leave home (De la Rosa et al., 2020).

Thus, this article aims to examine the state of the art of self-guided technology-mediated interventions based on CBT for adolescents. Through an integrative literature review, this study expects to map and present existing interventions as well as their main characteristics.

\section{METHOD}

Based on the proposed steps by Mendes, Silveira, and Galvão (2008), an integrative review was conducted. The guiding question was: what is the state of the art of self-guided technology-based CBT interventions for adolescents? In July 
2021, a search was performed in PsycINFO, Scopus, and Web of Science databases using the following descriptors organized into four blocks: [self-guided OR "self guided"] AND [app* OR intervention OR program OR therap* OR train* OR treatment $O R$ technique] AND [cbt OR cognitive OR cognitive-behav* OR i-cbt OR icbt] AND [adolesc* OR teen* OR youth OR "young people"].

Of the 93 results found, 32 were excluded for being duplicates. By reading the titles, abstracts, and keywords, the 61 remaining materials were screened. The following inclusion criteria were considered: being (1) a self-guided intervention (total or partial), (2) based on CBT techniques/that uses CBT techniques, and (3) aimed at adolescents. Among the 26 selected results were: empirical articles/protocols for empirical studies $(n=21)$ and theoretical material $(n=05)$. These papers were analyzed to identify interventions that met the inclusion criteria, and eight unpublished empirical articles/protocols for empirical studies replaced them in the final sample, which totaled 19 papers. The article selection process is depicted in Figure 1.

Categories were created regarding the studies' relevant aspects and the material was analyzed considering execution guidelines for internet-based interventions proposed by Proudfoot et al. (2011).

\section{RESULTS AND DISCUSSION}

Nineteen articles were found, which described 13 web-based cognitive-behavioral interventions for adolescents. The material is presented bellow.

\section{TYPES OF STUDIES AND INTERVENTIONS}

The 19 articles describe the 13 interventions through: seven efficacy studies with at least two groups (Calear et al., 2009; Hetrick et al., 2017; O'Kearney et al., 2006; Perry et al., 2017; Rapoff et al., 2014; Saulsberry et al., 2013; Van Voorhees et al., 2009), five efficacy studies protocols (Baldwin et al., 2021; Gladstone et al., 2015; Hides et al., 2020; Palermo et al., 2018; Rees et al., 2015), four pilot or preliminary data studies (Chillemi et al., 2020; Hill e Pettit, 2016; Rees et al., 2016; Wade et al., 2019), two complementary aspects studies - such as lessons learned and adherence (Anderson et al., 2017; Calear et al., 2013), and three case studies (March et al., 2019). Interventions and their main characteristics are described in Table 1.

Just over a third of the articles (36.8\%) are about efficacy studies with two groups, indicating how incipient mobile health research with adolescents is. This field faces specific challenges. Application development requires multidisciplinary partners collaboration with experience in software development (Price et al., 2014), and technical difficulties are often associated with the use of new technologies (Clough and Casey, 2015). Maintaining and updating such interventions can be challenging due to funding constraints as well as security, privacy, and sustainability issues (Price et al., 2014).

Nine studies showed favorable results for these interventions' use (Calear et al., 2009; Chillemi et al., 2020; Hill and
Pettit, 2016; March et al., 2019; Perry et al., 2017; Rapoff et al., 2014; Rees et al., 2016; Saulsberry et al., 2013; Wade et al., 2019). Despite this, it is concerning how much the number of interventions found in this study contrasts with the number and pace at which e-Health apps are being released in app stores (Olff, 2015). In 2013, it was estimated that there were over 10,000 mental health apps available for download (Ben-Zeev et al., 2013). However, research is needed to assess safety and effectiveness of mental health apps for children and adolescents (Grist et al., 2017). The high number of mental health apps available on the market without any evidence of effectiveness is potentially problematic, as ineffective interventions can have significant user costs (Price et al., 2014).

Among the articles found, only a single one reviewed the process experience of the intervention following the efficacy study, elaborating considerations for future research regarding online symptom assessment, risk management, maximizing engagement, minimizing sample loss, treatment fidelity, usability, integration, and sustainability (Anderson et al., 2017). Considering the likelihood of dropout in online interventions (Richardson et al., 2010) or even the difficulty in getting respondents observed in one of the articles (Hetrick et al., 2017), studies of this type are as necessary as those of effectiveness. This understanding is reinforced by findings supporting that poor usability (user experience in interacting with the app) may be the main cause of failure to adopt health technologies (Price et al., 2014).

\section{INTERVENTIONS' FOCUS}

The main therapeutic focuses of the interventions were: anxiety (Anderson et al., 2017; Baldwin et al., 2021; Calear et al., 2009; Calear et al., 2013; March et al., 2019; O'Kearney et al., 2006; Rees et al., 2015; Rees et al., 2016), depression (Baldwin et al., 2021; Calear et al., 2009; Calear et al., 2013; Gladstone et al., 2015; O'Kearney et al., 2006; Perry et al., 2017; Saulsberry et al., 2013; Van Voorhees et al., 2009) and suicide (Hetrick et al., 2017; Hill and Pettit, 2016). Drug use and psychotic experiences (Hides et al., 2020), cyberbullying (Chillemi et al., 2020), psychological well-being improvement in clinical conditions such as sickle cell anemia (Palermo et al., 2018), migraine (Rapoff et al., 2014), and rehabilitation after brain tumor (Wade et al., 2019) were also targets of these interventions.

The interventions focus primarily on the most common mental health symptoms in adolescents - anxiety and depression - and a worrying cause of death in this group - suicide (PAHO, 2018). But they also aim to help in cyberbullying, a phenomenon that is becoming increasingly common among young people (Mohseny et al., 2020), and in improving psychological well-being in clinical conditions, in line with e-Health interventions, which are growing rapidly (Shahid et al., 2021).

\section{Media used}

The interventions are both offered exclusively on a website $(n=9)$ (Anderson et al., 2017; Baldwin et al., 2021; Calear 
et al., 2009; Calear et al., 2013; Gladstone et al., 2015; Hetrick et al., 2017; Hides et al., 2020; March et al., 2019; O'Kearney et al., 2006; Perry et al., 2017; Rees et al., 2015; Rees et al., 2016; Saulsberry et al., 2013; Van Voorhees et al., 2009; Wade et al., 2019), such as via website with a smartphone app ( $n=$ 1) (Palermo et al., 2018), and also via online program $(n=1)$ (Chillemi et al., 2020), online web platform $(n=1)$ (Hill and Pettit, 2016), or even CD-ROM ( $n=1$ ) (Rapoff et al., 2014). Almost all of these interventions can be delivered on mobile devices, following World Health Organization (WHO, 2019) guidelines that digital health interventions be accessible through these technologies. Only one out of the 13 interventions uses CD-ROM, which does not work on mobile devices, not meeting WHO (2019) recommendations.

\section{Human SupPorT}

Eight of these interventions were entirely self-guided (Anderson et al., 2017; Baldwin et al., 2021; Calear et al., 2009; Calear et al., 2013; Chillemi et al., 2020; Hides et al., 2020; Hill and Pettit, 2016; O'Kearney et al, 2006; Palermo et al, 2018; Perry et al. 2017; Rees et al., 2015; Rees et al., 2016); three relied on human support (Gladstone et al., 2015; Rapoff et al., 2014; Saulsberry et al., 2013; Van Voorhees et al., 2009; Wade at el., 2019); one allowed support from a professional, if needed (Hetrick et al., 2017); and one had two possibilities: 1) to be performed entirely self-guided; or 2) self-guided, and from halfway through the treatment, if indicated, with the assistance of a therapist (March et al., 2019). When professional support was provided, it took place weekly, synchronously (by phone, videoconference, or synchronous chat) or asynchronously (via e-mail). Support was offered either initiated by the therapist himself or occurring in response to patients' questions/concerns.

Most interventions in this study are entirely self-guided, which may be a problem for treatment adherence, as dropout rates in entirely self-guided interventions are high (Richardson et al., 2010). When support from a professional is offered, it is most often provided synchronously. Although synchronous communication is thought to have better effects in a mental health treatment than asynchronous, Berger's (2017) review found no significant differences in the therapeutic alliance of patients who performed web-based interventions synchronously compared to those who performed asynchronously. Berger's (2017) study suggests that patients can establish a positive therapeutic alliance in internet interventions regardless of the form of communication, whether synchronous or asynchronous.

\section{Caregiver Participation}

Across the studies, five interventions include some level of caregiver participation (Anderson et al., 2017; Baldwin et al., 2021; Palermo et al., 2018; Rapoff et al., 2014; Rees et al., 2015; Rees et al., 2016; Gladstone et al., 2015; Saulsberry et al, 2013; Van Voorhees et al., 2009) and eight do not (Calear et al., 2009; Calear et al., 2013; Chillemi et al., 2020; Hetrick et al., 2017; Hides et al., 2020; Hill and Pettit, 2016; March et al., 2019; O'Kearney et al., 2006; Perry et al., 2017; Wade et al., 2019). Even in more traditional ways of offering mental health interventions to adolescents, the importance that parents and caregivers can have in acting adjunctively to treatment is recognized. In a 2016 investigation by the Association for Young People's Health [AYPH], it was documented that caregivers often don't feel they receive information to provide appropriate support at home, even when their children receive mental health care. The same document indicated concern about worsening crises due to parental anxiety itself. Thus, the articulation of caregivers (even with the availability of informational materials) can promote beneficial effects. It is important that future research in adolescent mental health interventions investigate in a structured way the impact on outcomes found considering different levels of parental integration.

\section{LIMITATIONS}

Among limitations of this study, it is recognized that by stipulating that the intervention should name itself self-guided, this may have excluded programs with such a characteristic that do not name themselves in this way. The lack of common terminology is a methodological difficulty characteristic of the field (Proudfoot et al., 2011). Another limitation is a possible selection bias since the article selection process was done by one reviewer.

\section{CONCLUSION}

This integrative review points out that well-designed and tested web-based cognitive-behavioral interventions for prevention and promotion of psychological well-being in adolescents can be effective and have potential to optimize and streamline mental health care for this group. However, mobile mental health research with adolescents is still in its early stages and faces challenges specific to this field, which involves multidisciplinary collaboration in developing technologies.

It is hoped that this review may constitute a starting point for a better understanding and improvement of projects and interventions that contemplate technology-mediated self-guided CBT for adolescents. Studies on these interventions can be of great value in a youthful country marked by inequalities such as Brazil, where many adolescents don't receive mental health treatment.

Further studies are needed to examine: aspects that promote or inhibit the effectiveness of the interventions; factors involved in adherence to them; and the role of professionals and/ or caregivers in these interventions. Moreover, it is essential to disseminate research results to the target audience in accessible language. Given the high number of apps available on the market that have not been investigated, disseminating the benefits of using evidence-based interventions among young people is a primary task of researchers and professionals.

Finally, refining the investigation of mental health apps allows better understanding and improvement of these devices. 
Elements of interventions that favor engagement and expected outcomes can be better explored with the target population. In this sense, such information can be useful to direct resources to develop or improve internet-based cognitive-behavioral interventions more effectively.

\section{REFERENCES}

Anderson, R. A., Rees, C. S., \& Finlay-Jones, A. L. (2017). Internet-based cognitive-behavioural therapy for young people with obsessivecompulsive disorder: Lessons learned. Journal of Obsessive-Compulsive and Related Disorders, 15, 7-12. https://doi.org/10.1016/j. jocrd.2017.08.001

Cambridge Dictionary. (2021). App. https://dictionary.cambridge.org/us/ dictionary/english/app

Association for Young People's Health (AYPH) (2016). Supporting young people with mental health problems: Results of a survey of parents. AYPH. http://www.youngpeopleshealth.org.uk/wp-content/ uploads/2016/11/AYPH-Parenting-briefing-11-nov-2016.pdf

Baldwin, P. A., Rasmussen, V., Trollor, J. N., Zhao, J. L., Anderson, J., Christensen, H., \& Boydell, K. (2021). IDTWO: A Protocol for a Randomised Controlled Trial of a Web-Based Mental Health Intervention for Australians with Intellectual Disability. International Journal of Environmental Research and Public Health, 18(5), 2473. https://doi. org/10.3390/ijerph18052473

Ben-Zeev, D., Kaiser, S. M., Brenner, C. J., Begale, M., Duffecy, J., \& Mohr, D. C. (2013). Development and usability testing of FOCUS: A smartphone system for self-management of schizophrenia. Psychiatric Rehabilitation Journal, 36(4), 289-296. https://doi.org/10.1037/prj0000019

Berger, T. (2017). The therapeutic alliance in internet interventions: A narrative review and suggestions for future research, Psychotherapy $R e$ search, 27(5), 1-14 https://doi.org/10.1080/10503307.2015.1119908

Borgueta, M. A., Purvis, C. K., \& Newman, M. G. (2018). Navigating the ethics of Internet-guided self-help interventions. Clinical Psychology Science and Practice, 25(2), e12235. https://doi.org/10.1111/cpsp.12235

Brooks, S. K., Webster, R. K., Smith, L. E., Woodland, L., Wessely, S., Greenberg, N., \& Rubin, G. J. (2020). The psychological impact of quarantine and how to reduce it: rapid review of the evidence. The Lancet, 395 (10227), 912-920. https://doi.org/10.1016/s0140-6736(20)30460-8

Calear, A. L., Christensen, H., Mackinnon, A., Griffiths, K. M., \& O’Kearney, R. (2009). The YouthMood Project: A cluster randomized controlled trial of an online cognitive behavioral program with adolescents. Journal of Consulting and Clinical Psychology, 77(6), 1021-1032. https://doi.org/10.1037/a0017391

Calear, A. L., Christensen, H., Mackinnon, A., \& Griffiths, K. M. (2013). Adherence to the MoodGYM program: Outcomes and predictors for an adolescent school-based population. Journal of Affective Disorders, 147(1-3), 338-344. https://doi.org/10.1016/j.jad.2012.11.036

Chillemi, K., Abbott, J.-A. M., Austin, D. W., \& Knowles, A. (2020). A Pilot Study of an Online Psychoeducational Program on Cyberbullying That Aims to Increase Confidence and Help-Seeking Behaviors Among Adolescents. Cyberpsychology, Behavior, and Social Networking, 23(4), 253-256. https://doi.org/10.1089/cyber.2019.0081

Clough, B. A., \& Casey, L. M. (2015). The smart therapist: A look to the future of smartphones and $m$ Health technologies in psychotherapy. Professional Psychology: Research and Practice, 46(3), 147-153. https://doi.org/10.1037/pro0000011
Cybulski, L., Ashcroft, D.M., Carr, M.J., Garg, S., Chew-Graham, C. A., Kapur, N., \& Webb, R. T. (2021). Temporal trends in annual incidence rates for psychiatric disorders and self-harm among children and adolescents in the UK, 2003-2018. BMC Psychiatry, 21(229). https://doi. org/10.1186/s12888-021-03235-w

De la Rosa, A., Moreyra, L. \& De la Rosa, N. (2020). Intervenciones eficaces vía Internet para la salud emocional en adolescentes: Una propuesta ante la pandemia por COVID-19. Hamut'ay, 7(2), 18-33. https://doi. org/10.21503/

Fegert, J. M., Vitiello, B., Plener, P. L., \& Clemens, V. (2020). Challenges and burden of the Coronavirus 2019 (COVID-19) pandemic for child and adolescent mental health: a narrative review to highlight clinical and research needs in the acute phase and the long return to normality. Child and adolescent psychiatry and mental health, 14, 20. https:// doi.org/10.1186/s13034-020-00329-3

Gladstone, T. G., Marko-Holguin, M., Rothberg, P., Nidetz, J., Diehl, A., DeFrino, D. T., Harris, M., Ching, E., Eder, M., Canel, J., Bell, C., Beardslee, W. R., Brown, C. H., Griffiths, K., \& Van Voorhees, B. W. (2015). An internet-based adolescent depression preventive intervention: study protocol for a randomized control trial. Trials, 16, 203. https:// doi.org/10.1186/s13063-015-0705-2

Grist, R., Porter, J., \& Stallard, P. (2017). Mental Health Mobile Apps for Preadolescents and Adolescents: A Systematic Review. Journal of medical Internet research, 19(5). https://doi.org/10.2196/ jmir.7332

Hetrick, S. E., Yuen, H. P., Bailey, E., Cox, G. R., Templer, K., Rice, S. M., Bendall, S., \& Robinson, J. (2017). Internet-based cognitive behavioural therapy for young people with suicide-related behaviour (ReframeIT): a randomised controlled trial. Evidence Based Mental Health, 20(3), 76-82. https://doi.org/10.1136/eb-2017-102719

Hides, L., Baker, A., Norberg, M., Copeland, J., Quinn, C., Walter, Z., .. Kavanagh, D. (2020). A Web-Based Program for Cannabis Use and Psychotic Experiences in Young People (Keep It Real): Protocol for a Randomized Controlled Trial. JMIR research protocols, 9(7). https:// doi.org/10.2196/15803

Hill, R. M., \& Pettit, J. W. (2016). Pilot Randomized Controlled Trial of LEAP: A Selective Preventive Intervention to Reduce Adolescents' Perceived Burdensomeness. Journal of Clinical Child \& Adolescent Psychology, 48(1), 45-56. https://doi.org/10.1080/15374416.2016.1188705

Kuhn, D. (2006). Do cognitive changes accompany developments in the adolescent brain? Perspectives on Psychological Science, 1(1), 59-67. https://doi.org/10.1111/j.1745-6924.2006.t01-2-.x

Liang, L., Ren, H., Cao, R., Hu, Y., Qin, Z., Li, C., \& Mei, S. (2020). The Effect of COVID-19 on Youth Mental Health. The Psychiatric quarterly, 91(3), 841-852. https://doi.org/10.1007/s11126-020-09744-3

Lopes, C. S., Abreu, G. A., Santos, D. F., Menezes, P. R., Carvalho, K. M. B., Cunha, C. F., ... Szklo, M. (2016). ERICA: Prevalência de transtornos mentais comuns em adolescentes brasileiros. Revista de Saúde Pública, 50(1). https://doi.org/10.1590/s015188787.2016050006690

March, S., Donovan, C. L., Baldwin, S., Ford, M., \& Spence, S. H. (2019). Using stepped-care approaches within internet-based interventions for youth anxiety: Three case studies. Internet interventions, 18, 100281. https://doi.org/10.1016/j.invent.2019.100281

Mehta, S., Peynenburg, V. A., \& Hadjistavropoulos, H. D. (2018). Internetdelivered cognitive behaviour therapy for chronic health conditions: A systematic review and meta-analysis. Journal of Behavioral Medicine, 42, 169-187. https://doi.org/10.1007/s10865-018-9984-x 
Mendes, K. D. S., Silveira, R. C. de C. P., \& Galvão, C. M. (2008). Revisão integrativa: Método de pesquisa para a incorporação de evidências na saúde e na enfermagem. Texto \& Contexto - Enfermagem, 17(4), 758-764. https://doi.org/10.1590/s0104-07072008000400018

Mohseny, M., Zamani, Z., Akhondzadeh Basti, S., Sohrabi, M., Najafi, A., \& Tajdini, F. (2020). Exposure to Cyberbullying, Cybervictimization, and Related Factors Among Junior High School Students. Iran J Psychiatry Behav Sci, 14(4), e99357. https://dx.doi.org/10.5812/ijpbs.99357

O'Kearney, R., Gibson, M., Christensen, H., \& Griffiths, K. M. (2006). Effects of a Cognitive-Behavioural Internet Program on Depression, Vulnerability to Depression and Stigma in Adolescent Males: A School-Based Controlled Trial. Cognitive Behaviour Therapy, 35(1), 43-54. https://doi.org/10.1080/16506070500303456

Olff, M. (2015). Mobile mental health: a challenging research agenda. European Journal of Psychotraumatology, 6(1). https://doi. org/10.3402/ejpt.v6.27882

Palermo, T. M., Zempsky, W. T., Dampier, C. D., Lalloo, C., Hundert, A. S., Murphy, L. K., ... Stinson, J. N. (2018). iCanCope with Sickle Cell Pain: Design of a randomized controlled trial of a smartphone and web-based pain selfmanagement program for youth with sickle cell disease. Contemporary Clinical Trials, 74, 88-96. https://doi.org/10.1016/j.cct.2018.10.006

Pan American Health Organization (PAHO). (2018). Saúde mental dos adolescentes. https://www.paho.org/pt/topicos/saude-mental-dos-adolescentes?option=com_content \&view=article\&id=5779 :folha-informativa-saude-mental-dos-adolescentes\&ltemid=839

Perry, Y., Werner-Seidler, A., Calear, A., Mackinnon, A., King, C., Scott, J., ... Batterham, P. J. (2017). Preventing Depression in Final Year Secondary Students: School-Based Randomized Controlled Trial. Journal of medical Internet research, 19(11), e369. https://doi.org/10.2196/jmir.8241

Price, M., Yuen, E. K., Goetter, E. M., Herbert, J. D., Forman, E. M., Acierno, R. \& Ruggiero, K. J. (2014). mHealth: A mechanism to deliver more accessible, more effective mental health care. Clinical Psychology \& Psychotherapy, 21(5), 427-436. https://doi. org/10.1002/cpp.1855.

Proudfoot, J., Klein, B., Barak, A., Carlbring, P., Cuijpers, P., Lange, A., ... Andersson, G. (2011). Establishing guidelines for executing and reporting Internet intervention research. Cognitive behaviour therapy, 40(2), 82-97. https://doi.org/10.1080/16506073.2011.573807

Pupo-González, L., Nogueras-Reyes, Y., de-Prada-Justel, M., \& Labrada-Pupo, D. (2018). Salud mental infanto juvenil, características de una problemática actual. Revista Electrónica Dr. Zoilo E. Marinello Vidaurreta, 43 (6 Especial). http://www.revzoilomarinello.sld.cu/index.php/zmv/ article/view/1687

Ravens-Sieberer, U., Kaman, A., Otto, C., Adedeji, A., Devine, J., Erhart, M., ... Hurrelmann, K. (2020). Mental Health and Quality of Life in Children and Adolescents During the COVID-19 Pandemic-Results of the Copsy Study. Deutsches Arzteblatt international, 117(48), 828-829. https://doi.org/10.3238/arztebl.2020.0828

Rees, C. S., Anderson, R. A. \& Finlay-Jones, A. (2015). OCD? Not Me! Protocol for the Development and Evaluation of a Web-based self-guided Treatment for Youth with Obsessive-Compulsive Disorder. BMJ Open, 5(4), 1-10. https://doi.org/ 10.1136/bmjopen-2014-007486

Rees, C., Anderson, R., Kane, R. \& Finlay-Jones, A. (2016). Online Obsessive-Compulsive Disorder Treatment: Preliminary Results of the "OCD? Not Me!" Self-Guided Internet-Based Cognitive Behavioral Therapy Program for Young People. Journal of Medical Internet Research, 3(29), 1-11. https://doi.org/e29. 10.2196/mental.5363.
Richardson, T., Stallard, P., \& Velleman, S. (2010). Computerised Cognitive Behavioural Therapy for the Prevention and Treatment of Depression and Anxiety in Children and Adolescents: A Systematic Review. Clinical child and family psychology review, 13(3), 275-290. https:// doi.org/10.1007/s10567-010-0069-9

Saulsberry, A., Marko-Holguin, M., Blomeke, K., Hinkle, C., Fogel, J., Gladstone, T., ... Van Voorhees, B. W. (2013). Randomized Clinical Trial of a Primary Care Internet-based Intervention to Prevent Adolescent Depression: Oneyear Outcomes. Journal of the Canadian Academy of Child and Adolescent Psychiatry, 22(2), 106-117.https://pubmed.ncbi.nlm.nih.gov/23667356/

Rapoff, M. A., Connelly, M., Bickel, J. L., Powers, S. W., Hershey, A. D., Allen, J. R., ... Belmont, J. M. (2014). Headstrong Intervention for pediatric migraine headache: A randomized clinical trial. The Journal of Headache and Pain, 15(1), 12. https://doi.org/10.1186/1129-2377-15-12

Shahid, N., Rac, V. E., Bielecki, J., \& Berta W. (2021). Understanding factors critical to the implementation of ehealth in chronic disease management: A realist review protocol. BMJ Open, 11, e048250. doi: 10.1136/bmjopen-2020-048250

Silva, A. M. B. da, Silva, M. L. B. da, \& Enumo, S. R. F. (2017). Relações entre o hormônio cortisol e comportamentos de adolescentes: Uma revisão sistemática. Psicologia Revista, 26(2), 337-362. https://doi. org/10.23925/2594-3871.2017v26i2p.337-362

Spek, V., Cuijpers, P., Nyklícek, I., Riper, H., Keyzer, J., \& Pop, V. (2006). Internet-based cognitive behaviour therapy for symptoms of depression and anxiety: A meta-analysis. Psychological Medicine, 37(3), 319-328. https://doi.org/10.1017/s0033291706008944

Stefanopoulou, E., Lewis, D., Taylor, M., Broscombe, J., \& Larkin, J. (2018). Digitally Delivered Psychological Interventions for Anxiety Disorders: A Comprehensive Review. Psychiatric Quarterly, 90, 197-215. https://doi.org/10.1007/s11126-018-9620-5

Steinberg, L. (2016). Adolescence (11th ed., pp. 1-11). McGraw-Hill.

Substance Abuse and Mental Health Services Administration (SAHMA). (2019). Key substance use and mental health indicators in the United States: Results from the 2018 National Survey on Drug Use and Health (NSDUH). https://www.samhsa.gov/data/sites/default/files/ cbhsq-reports/NSDUHNationalFindingsReport2018/NSDUHNationalFindingsReport2018.pdf

Sztein, D. M., Koransky, C. E., Fegan, L., \& Himelhoch, S. (2017). Efficacy of cognitive behavioural therapy delivered over the Internet for depressive symptoms: A systematic review and meta-analysis. Journal of Telemedicine and Telecare, 24(8), 527-539. https://doi. org/10.1177/1357633×17717402

Topooco, N., Berg, M., Johansson, S., Liljethörn, L., Radvogin, E., Vlaescu, G., ... Andersson, G. (2018). Chat- and internet-based cognitive-behavioural therapy in treatment of adolescent depression: Randomised controlled trial. BJPsych open, 4(4), 199-207. https://doi. org/10.1192/bjo.2018.18

Van Voorhees, B. W., Fogel, J., Pomper, B. E., Marko, M., Reid, N., Watson, N., ... Domanico, R. (2009). Adolescent Dose and Ratings of an Internet-Based Depression Prevention Program: A Randomized Trial of Primary Care Physician Brief Advice versus a Motivational Interview. Journal of Cognitive and Behavioral Psychotherapies: The Official Journal of the International Institute for the Advanced Studies of Psychotherapy and Applied Mental Health, 9(1), 1-19.

Wade, S. L., Narad, M. E., Moscato, E. L., LeBlond, E. I., King, J. A., Raj, S. P., ... Salloum, R. (2019). A Survivor's Journey: Preliminary efficacy of an online problem-solving therapy for survivors of pediatric brain tumor. Pediatric Blood \& Cancer, 67(2), e28043. https://doi.org/10.1002/pbc.28043 
World Health Organization (WHO). (2019). WHO Guideline: Recommendations on Digital Interventions for Health System Strengthening. https:// apps.who.int/iris/bitstream/handle/10665/311941/9789241550505-eng.pdf?ua $=1$
Xie, X., Xue, Q., Zhou, Y., Zhu, K., Liu, Q., Zhang, J., \& Song, R. (2020). Mental Health Status Among Children in Home Confinement During the Coronavirus Disease 2019 Outbreak in Hubei Province, China. JAMA pediatrics, 174(9), 898-900. https://doi.org/10.1001/jamapediatrics.2020.1619 